\title{
NYMPHAL HABITAT OF OLIARUS VICARIUS (HOMOPTERA: CIXIIDAE), AND POSSIBLE ASSOCIATION WITH APHAENOGASTER AND PARATRECHINA (HYMENOPTERA: FORMICIDAE) ${ }^{1}$
}

\author{
By C. R. Thompson, ${ }^{2}$ J. C. Nickerson, ${ }^{3}$ And F. W. Mead ${ }^{3}$
}

Oliarus is a cosmopolitan genus represented in North America north of Mexico by 51 species (Mead 1968). The most recently published key is found in a preliminary revision by Ball (1934) in which 31 species of Oliarus are recognized. Mead (1968) showed that $O$. vicarius (Walker) and O. quinquelineatus (Say) are so similar in morphology and habits that misidentifications are made. Mead stated that $O$. vicarius ranges only from North Carolina southward to Florida and, with few exceptions, is restricted to the coastal plain. $O$. quinquelineatus is widespread in the eastern half of North America. Its range overlaps that of $O$. vicarius as far south as Gainesville, Florida.

Little is known of the nymphal habitat and behavior of $O$. vicarius. Prior to the report of Sheppard et al (1979) nymphs of $O$. vicarius were unknown. They were found by Sheppard et al (1979) in unoccupied galleries in mounds of the red imported fire ant, Solenopsis invicta Buren, and also in rotten stumps and logs. We here give further information on nymphal habitat and adult flight patterns. In addition, observations are given for 2 ant species frequently found with $O$. vicarius nymphs.

\section{MeThodS}

In 1976, O. vicarius nymphs and adults were found ca. $30 \mathrm{~km}$ east of Silver Springs, Florida, in stands of sand pine, Pinus clausa (Champm.) Vasey. Also present were saw-palmetto, Serenoa repens

\footnotetext{
${ }^{1}$ Florida Agricultural Experiment Station Journal Series No. 2139 and Contribution No. 462, Bureau of Entomology, Division of Plant Industry, Florida Department of Agriculture and Consumer Services.

${ }^{2}$ Department of Entomology and Nematology, University of Florida, Gainesville, FL 32611.

${ }^{3}$ Division of Plant Industry, Florida Department of Agriculture and Consumer Services, P. O. Box 1269, Gainesville, FL 32602.

Manuscript received by the editor January 18, 1980
} 
(Bartr.) Small, and one or more species of scrub oak, Quercus spp., typical of sand pine forest. $O$. vicarius nymphs were found beneath the numerous logs and stumps in mature stands of sand pine and oak. Records were made of nymphal chamber construction, log dimensions, and state of decay.

Late-instar nymphs were brought to the laboratory for rearing. $O$. vicarius nymphs, along with the rotten wood and wax fibers of their original chambers, were placed on moist cotton in Wilson cells. The ambient temperature was held at ca. $21^{\circ} \mathrm{C}$. A mass of eggs was kept in a tightly sealed shell vial with material from beneath the logs.

O. vicarius adults were recorded for the years 1969-76 from a blacklight trap located adjacent to turkey oak and pine woods at the Division of Plant Industry, Doyle Conner Building, Gainesville, Florida.

\section{Results AND Discussion}

When oak and pine stumps and logs were overturned, masses of wax fibers invariably indicated an $O$. vicarius chamber. The white, opaque, fluffly lining of the chambers consisted of numerous wax fibers (1-3 mm long) produced from wax plates on the abdomen of the nymphs (Mead 1968). When nymphs were disturbed, they appeared to drop their wax fiber "tails" or to knock them off while escaping.

Nymphs were found beneath logs and stumps ranging from dry and relatively decay-free to almost fully decayed and easily pulled apart; all were partially buried in the duff of the forest floor. Nymphal collection data are presented in Table 1.

The ant, Aphaenogaster carolinensis Wheeler, was collected on 5 occasions in or near the cixiid nymphal cells. When one stump was overturned, an Aphaenogaster worker grasped an O. vicarius nymph and attempted to escape. Nymphs were not attacked when placed in vials with unfed Aphaenogaster workers. Nymphs were also collected twice with another ant, Paratrechina vividula Nylander. These observations parallel those of Myers (1929) who found an association between Odontomachus brunneus Patton and cixiid nymphs of Mnemosyne cubana Stål.

Backlight collections of $O$. vicarius adults are summarized in Fig. 1. This trap was located approximately $80 \mathrm{~km}$ northwest of the study area. Adults were collected only from April through July. Nymphs 


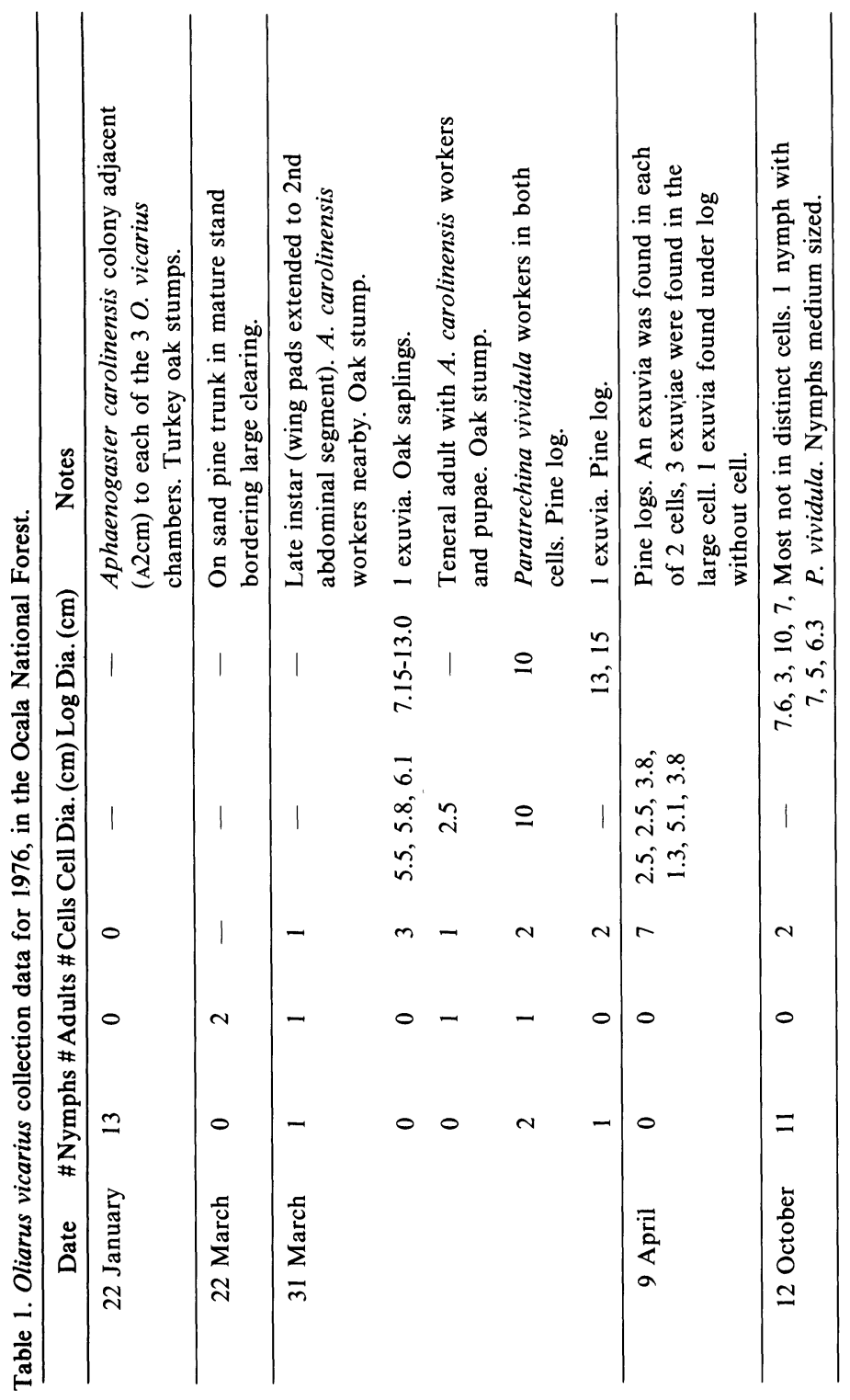


were found in rotten wood chambers January through March. One hundred seventeen nymphs hatched ca. 4 June from a mass of eggs collected 31 March beneath a log. In late March, a late-instar nymph and a teneral adult were collected, while only exuviae were found under the logs in early April. In October, medium-sized nymphs were found beneath logs. These data suggest a univoltine cycle in which these insects overwinter as late-instar nymphs, emerge, and mate during March-July. Eggs deposited under logs hatch, and the nymphs develop during the summer and fall.

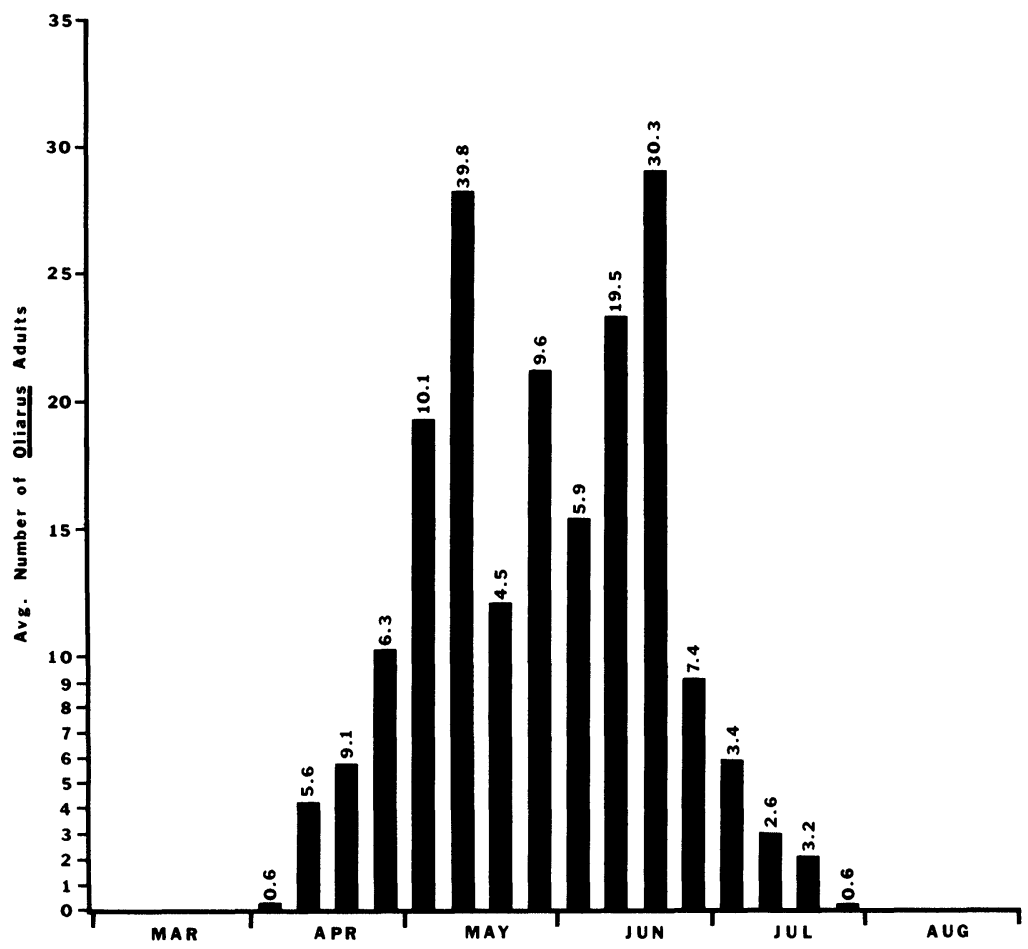

Fig. 1. Average weekly catch of Oliarus vicarius adults collected from a blacklight trap maintained at the Division of Plant Industry, Gainesville, for the years 1969-1976. No $O$. vicarius adults were captured during the months not shown. Confidence intervals are given for each average weekly collection. 


\section{CONCLUSIONS}

Wax-fiber lined chambers found beneath pine and oak logs or stumps indicate the habitat of the nymphs and teneral adults of $O$. vicarius. We suggest that some type of symbiotic relationship exists between $O$. vicarius and the ants, Aphaenogaster carolinensis and Paratrechina vividula. Such a relationship is indicated by the repeated collections of the ants, especially Aphaenogaster, and Oliarus in close proximity. It is also possible that the presence of Aphaenogaster and Oliarus under the same logs is the result of similar habitat requirements. We suspect that the Oliarus nymphs feed on the exposed roots of pine, saw-palmetto, or oak that are beneath the logs.

\section{ACKNOWLedgements}

We thank Mr. G. Hemingway of the U. S. Forest Service for permission to work within the Ocala National forest; and Dr. William F. Buren for identifying the ants.

\section{Literature Cited}

BaLl, E. D.

1934. The genus Oliarus and its allies in North America. J. Wash. Acad. Sci. 24(6):268-276.

MEAD, F. W.

1968. A revision of the genus Oliarus in North America, north of Mexico (Homoptera:Cixiidae). Ph.D. Dissertation. North Carolina State University. Raleigh, North Carolina xxxiv, 398 p., 595 fig.

MYERS, J. G.

1929. Observations on the biology of two remarkable cixiid plant-hoppers (Homoptera) from Cuba. Psyche 36(4):283-292, 1 pl.

Sheppard, C., P. B. Martin, and F. W. Mead.

1979. A planthopper (Homoptera:Cixiidae) associated with red imported fire ant (Hymenoptera:Formicidae) mounds. J. Georgia Entomol. Soc. 14(2): 140-144. 

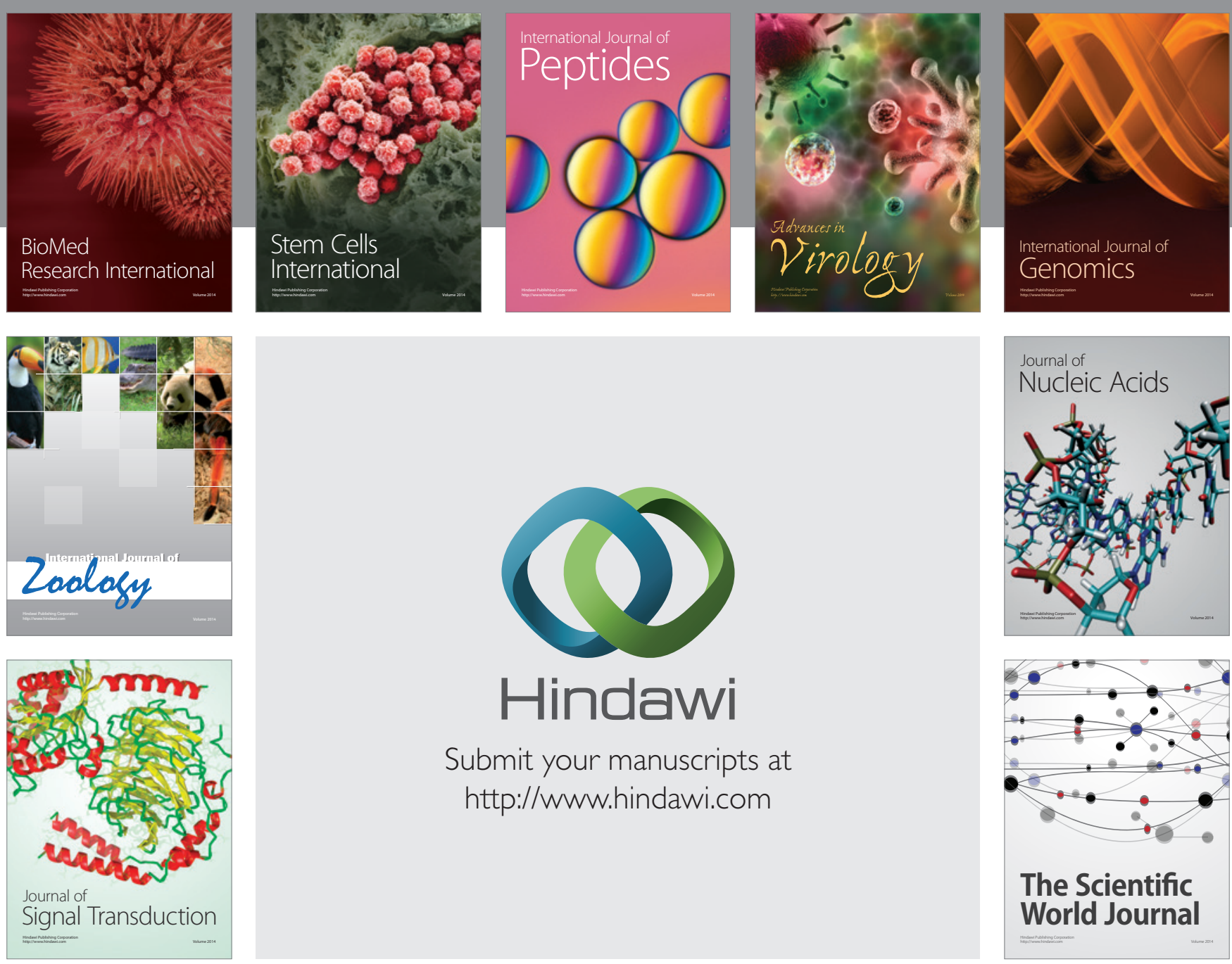

Submit your manuscripts at

http://www.hindawi.com
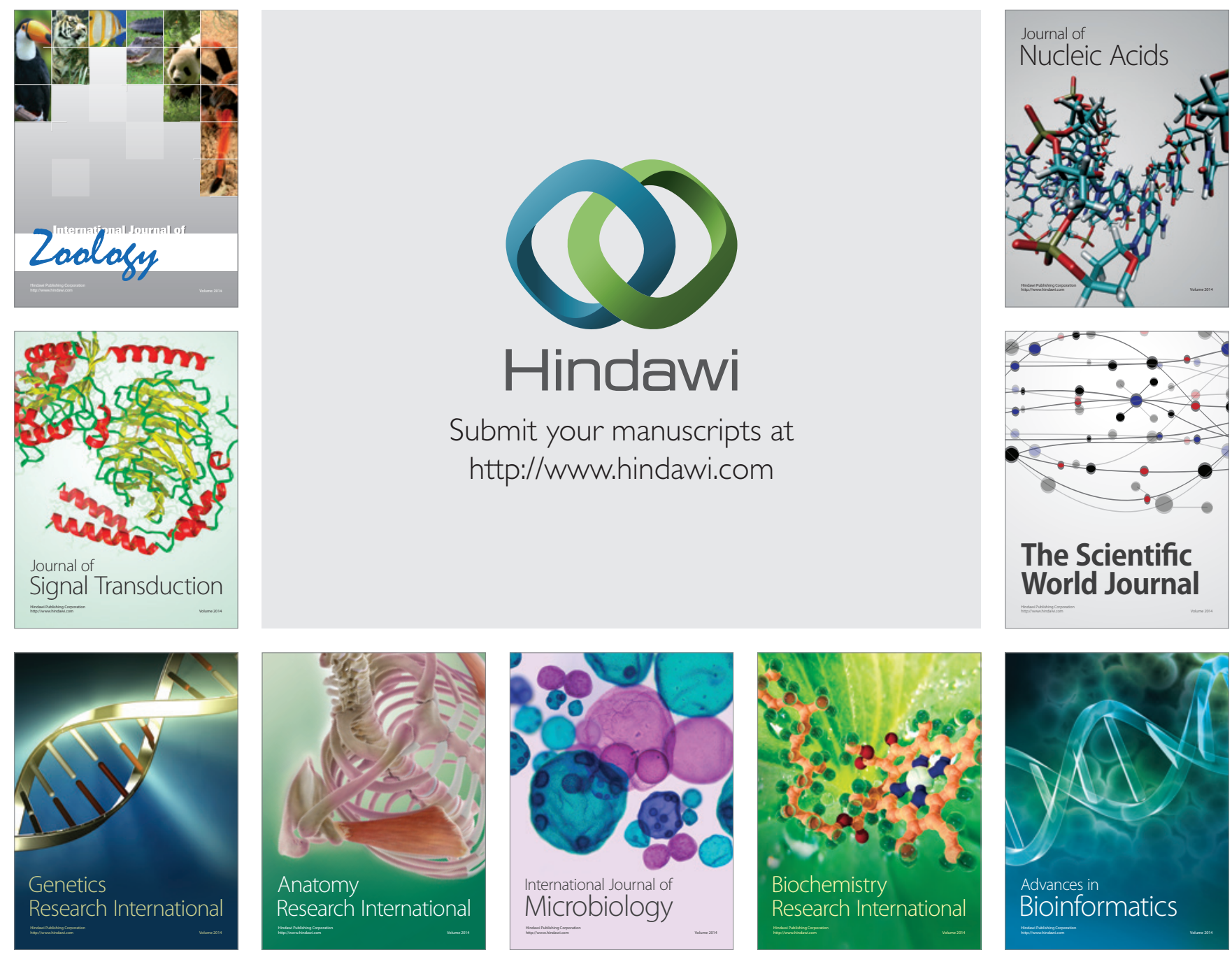

The Scientific World Journal
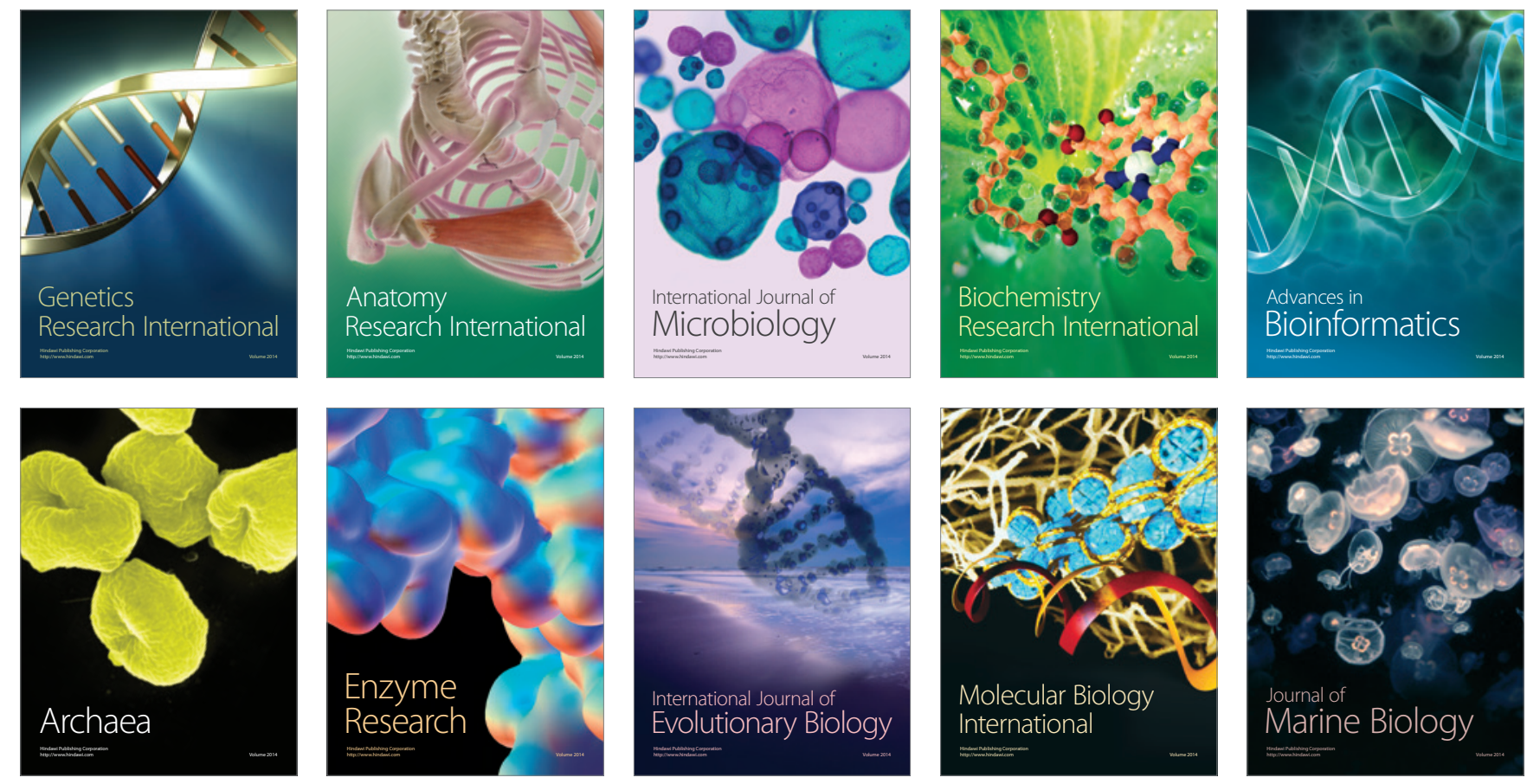